\title{
Proleptic modernism? A reconsideration of the literature of colonial Queensland
}

\author{
Belinda McKay \\ b.mckay@griffith.edu.au
}

\begin{abstract}
Susan Stanford Friedman argues that modernisms are multiple, polycentric and recurrent. This article takes up her invitation to focus on the circulation of people and ideas that connected modernisms from different parts of the planet by reconsidering two moments in the literature of colonial Queensland as instances of proleptic modernism. The publications of Policy and Passion by Rosa Praed in 1881 in London, and of the 'The Red Snake' by Francis Adams in 1888 in Brisbane encapsulate early manifestations of the cultural unease and destabilisation that drove the development of modernism/s as the expressive domain of modernity/ies. Striking thematic and stylistic parallels with the work of canonical modernists - HD in the case of Praed, and Conrad in the case of Adams - suggest not only that modernism began to manifest itself in Anglophone culture much earlier than is generally conceded, but also that the cognitive dissonance generated by the colonial experience was centrally implicated in its development.
\end{abstract}

\section{Introduction}

As an undergraduate in the English Department at the University of Queensland in the 1970s, I was taught that literary modernism was a form of aesthetic experimentation that emerged in European high cultural circles in the early twentieth century. Its canonical authors were T.S. Eliot, James Joyce and Virginia Woolf. Despite Eliot's American background, he and his modernist compatriots, such as Ezra Pound and HD, were treated as acculturated Europeans: their American experience in itself was not seen as contributing to the making of modernism. And although we students were conscious of studying 'moderns', examining the connection between modernism and modernity was less of a priority than becoming thoroughly immersed in a particular aesthetic, and learning to establish hierarchies of value: our 'taste' as literary critics was being formed - and let me hasten to add that I remain immensely grateful for this rigorous training. Although 'Queensland literature' was read (and indeed even written) by our lecturers, it was rarely taught, and the idea that the colonial experience in itself contributed to the development of high literary modernism in Europe would have seemed wrong-headed: the prevailing intellectual 
model was that - at least up until well beyond World War II — the metropolitan centre generated new cultural forms that rippled slowly and unevenly outwards to the Anglophone periphery.

The study of literary modernism today is so far removed from this position that the eminent American scholar Susan Stanford Friedman (2010: 473) can wonder 'have the field's boundaries become so boundless as to incorporate everything and thus lose all definitional cogency or analytic utility?' The centre-periphery model of the generation of culture has given way over recent decades to a model of flow and connection, which emphasises the intercolonial and transnational exchanges produced by cultures of movement. ${ }^{1}$ The empire not only writes back, but increasingly is understood to have contributed to the development of movements like modernism. The old understanding of modernism as an aesthetic rebellion in European high culture, tightly circumscribed both geographically and temporally, has given way to an exploration of modernism/s as the expressive domain of modernity/ies. Disruptive aesthetic practices increasingly are seen as part of a broader, longer conflict between tradition and modernity that erupts with urgency in many cultures at sporadic intervals: modernisms, according to Friedman, are multiple, polycentric and recurrent.

\section{Circulation}

Among several new ways of approaching the study of literary modernism without giving up on 'definitional cogency or analytic utility', Friedman suggests a focus on circulation:

Circulation is the archive of mobility, calling for the act of seeing linkages, networks, conjunctures, creolisations, intertextualities, travels, and transplantations connecting modernisms from different parts of the planet. Often the pathways are the routes born of colonialism, passages to India, Africa, or the Caribbean by western writers like Forster or Conrad; passages to the colonisers' metropole by writers like Jean Rhys, Mulk Raj Anand, or Tayeb Salih. How is that relationality experienced, reflected upon, represented? What is the interplay of roots and routes in those circulations across the globe? Unlike a centre-periphery model, circulation stresses the interactive and dynamic, assuming multiple agencies, centres, and conjunctures around the world. (2010: 493, emphasis in original)

This change of perspective from a centre-periphery model to a circulation model allows us to see that modernity and modernism did not spring, like Athena, fully armed from the head of Zeus; rather, they were the culmination of a process of cultural change that gathered momentum during the final decades of the nineteenth century so that 'on or about December 1910', as Virginia Woolf (1924: 4) playfully claims, 'human character changed'. When we look at the role of circulation in that process, contact zones emerge clearly as engines of modernity/modernism, driving change in both local and metropolitan culture. Often loci of brutality and barbarism, contact zones generate rapid change and forge new conjunctures: in this article, I suggest that frontier violence was a source of cognitive dissonance that colonial subjects brought to metropolitan culture as a destabilising force that collapsed the centre-periphery dichotomy and opened up new possibilities of thinking about nature and culture. Although Queensland can claim no Katherine Mansfield - a major contributor to the development of the interior monologue as a 
key innovation in high literary modernism - we have been blind to some earlier literary developments that foreshadowed modernism and even contributed to its development.

Late nineteenth-century Queensland was an experiment in mobility, conflict and transculturation. In the wake of the frontier wars, which were especially violent and continued sporadically well into the 1890 s — at least in the north - Aboriginal people were displaced or forcibly removed from their traditional lands. Following free settlement in 1842 and gathering further momentum after separation from New South Wales in 1859, successive waves of transnational and intercolonial immigration and emigration, responding to 'boom and bust' economic conditions including gold rushes and land grabs, produced a highly decentralised and mobile white population. ${ }^{2}$ From the 1860 s to 1904 , 'blackbirded' Pacific Islanders and other non-white peoples provided the main labour base for the sugar plantations. I have observed elsewhere (McKay 2001) that in Queensland literature a preoccupation with the transgression of racial and sexual boundaries reflected public debates on 'dying race' versus assimilation theories and policies in the late nineteenth and early twentieth centuries. However, by focusing on how Queensland writers participate in the 'linkages, networks, conjunctures, creolisations, intertextualities, travels, and transplantations' that Friedman identifies as connecting modernisms around the globe, it is possible to see this local pattern as part of a much more widespread crisis in culture that was shaping Anglophone modernity and modernism.

In this article, I ask the reader to reconsider two unsettling moments in Queensland literature as instances of proleptic modernism - in other words, as anticipative of literary modernism, or even (in the medical sense of the word) as predictive or prognostic of it. The first moment is the publication in 1881 of Policy and passion by Rosa Praed, one of those colonial subjects who made her home in England in early adulthood, but who in her personal life and writing cultivated a transnational identity in which the colonial experience was an essential component of cosmopolitanism. The second moment is the publication in Brisbane in 1888 of 'The Red Snake' by the peripatetic intellectual Francis Adams. In both cases, the writers thrust the cognitive dissonance of the colonial experience into the comfortable drawing rooms of the educated middle classes.

\section{Rosa Praed}

Rosa Praed (1851-1935), who was born in what is now Queensland before the colony separated from New South Wales, had first-hand experience of frontier violence. Her father, Thomas Lodge Murray-Prior, settled his family on a succession of properties in areas of recent or even current frontier conflict - Logan, the south Burnett and Maroon. Among young Rosa's many Aboriginal playmates was mixed-race Jenny, who was 'adopted' by Thomas Lodge Murray-Prior in 1856 in circumstances that suggest that she may have been his child. ${ }^{3}$ In 1857, when Rosa was six years old, the Murray-Priors (and Jenny) were living at Hawkwood in the south Burnett when Aboriginal people murdered twelve members and dependants of the Fraser family at nearby Hornet Bank station. In the ensuing punitive massacres, in which Rosa's father participated, hundreds of Aboriginal people were killed. ${ }^{4}$ In her autobiographical Australian Life: Black and White, Rosa Praed 
(1885: 27) wrote, 'I have not ceased to dream that I am on an outstation besieged by Blacks', and throughout her life she revisited the Hornet Bank massacre in recurrent nightmares and 'phantasmagoric visions' that she increasingly substituted for historical veracity. ${ }^{5}$ In some of these visions, Praed believed she was being pursued by Aboriginal people, and later became preoccupied with the lost voices of the culture destroyed by white conquest: in the absence of any dialogue with Aboriginal people, the void was filled by disembodied voices conjured up by spiritualism. For Praed, Hornet Bank represented the 'founding trauma' that Dominick LaCapra (2001: 23) proposes as the basis not only for identity but for 'entry into the extraordinary'; in Praed's case, this was the imaginative practice of writing, which she began in childhood.

For Rosa, a daughter of the squattocracy, the other face of colonial horror was colonial gentility, a paradox explored repeatedly in her Australian novels. From the age of eleven, when her father became Post-Master General and then a Member of the Legislative Assembly of the newly separated colony of Queensland, Rosa was exposed to life at the hub of colonial politics in Brisbane, and after her mother died - worn out by consumption and twelve confinements - she became her father's hostess. Her many novels that draw on this context reveal not only a keen grasp of political intrigue and an acute sense of the asymmetrical power relations between men and women, but also an awareness of the linkages and exchanges forged by the colonial experience. In 1872, twenty-one-year-old Rosa Murray-Prior married Englishman Campbell Praed; after a failed attempt at running cattle on desolate Curtis Island, which set the tone for their unhappy marriage, the couple sailed for England in 1878. They separated in 1897, and Praed lived with psychic medium Nancy Harward until Nancy's death in 1927. Following her only return visit to Australia, in 1894-95, she visited the Far East; and from the 1880s, she spent winters abroad, mostly on the Riviera but also in Morocco and Algeria. Indeed, Julianne Lamond (2012: 34) observes that place 'is negotiated in Praed's novels through figuring the movement of individuals between England and parts of its colonial network, as well as other countries, something that also pertains to Praed herself'.

In 1881, as Praed's new publisher George Bentley read the proofs of her second novel Policy and Passion, he became increasingly disturbed by the explicitness of the treatment of the attempted seduction of Honoria Longleat, daughter of the Premier of 'Leichardt's Land', by the aristocratic English cad Hardress Barrington. ${ }^{6}$ Citing the novel's 'horrid atmosphere' and 'repulsive' sexual scenes, its 'coarse' characters and the 'animal quality' of the seducer's conversations, Bentley exhorted Praed to 'tone down, tone down, tone down'. She responded that in Australia, 'There is less varnish - situations must be more unconventional', and that she feared 'losing the unity of [her] conception' if she made any cuts. Her friend Frederick Sartoris concurred with Bentley, finding 'unmanly violence' in an Englishman of Barrington's social standing to be 'repugnant'. Sexual violence perpetrated against women by powerful men had been an important concern of Gothic novels in an earlier era, but Praed's novel introduces something new in the realism of its treatment of the governance of colonial society, its entanglement of the domestic and political spheres, and the worldly perspective of the implicitly female voice of the narrator. Although she had little choice but to excise much of the offending material from Policy and Passion, Praed continued to destabilise the faultlines of race, gender and sexuality throughout her career. 
The settings of Praed's novels - whether metropolitan London, the colonial capital Leichardt's Town or the remote Never-Never Land — are invariably laboratories of cosmopolitanism that reshape the consciousness of the central characters and redefine power structures in the pursuit of an ambiguous and conflicted modernity. Identifying asymmetrical power relations as the root cause of male violence against women, Praed feminised the concept of mateship to develop the ideal of a 'true mate' marriage based on equality. Spiritualism - which Helen Sword has shown in Ghostwriting Modernism (2002) to be a major influence on modernism - as well as related forms of esotericism provided models for alternative forms of female empowerment. Reinforced by her relationship with Harward from the late 1890s, spiritualism legitimated not only the feminisation but also the queering of Praed's writing: Sister Sorrow (1916), for instance, explores same-sex desire. ${ }^{7}$

A further important influence on Praed's work - again shared by many modernists - was her attraction to the Irish nationalist movement, which led her to draw parallels between the dispossession of the Irish and the dispossession of Aboriginals in Australia, most notably in the 1915 novel Lady Bridget in the NeverNever Land (Praed 1987). ${ }^{8}$ Despite this insight, however, Praed's treatment of race is deeply imbued with primitivism and eugenicism. The volatile mix of colonial guilt and theosophical ideas could produce escapist fantasies such as Fugitive Anne (1902), in which a woman escapes from her husband into the wilds of Cape York, is hailed as a goddess by Aboriginal people and subsequently becomes the high priestess of a lost Mayan civilisation. Praed hints at the sexual attraction between Anne and her Aboriginal servant Kombo ('comboism' was a euphemism for interracial sexual relations), but ultimately Anne marries a white anthropologist and Kombo is reduced to an exhibit on their lecture circuit. As I have argued elsewhere (McKay 2001), Praed's pursuit of the empowerment of white women and the moral redemption of the white race serves to exculpate white settlers and comes at the expense of the humanity of Aboriginal characters.

The proleptic modernism of Praed's work lies in her psychologisation of her female characters, her renegotiation of gender roles and power structures, the progressive queering of her work and her preoccupation with the paradox that horror and gentility are inextricably twinned. Destabilisation, fragmentation and disembodiment are hinted at in her fiction from the beginning, but the influence of spiritualism multiplied the voices in her later novels, some of which were written in collaboration with Harward. Although Praed's work is not particularly innovative in style and technique, her twinned souls, past selves and disembodiments foreshadow the Doppelgänger of Robert Louis Stevenson, the personae of Pound and Eliot, and the multiple consciousnesses of Woolf. In particular, there are striking parallels with the American expatriate modernist HD (1886-1961), whose work profoundly shapes Friedman's thinking about modernism (see Friedman 1981, 1990). Although there is no direct connection between these two writers, both were expatriates whose work worries away at the faultline between the tectonic plates of settler dispossessory and metropolitan culture.

Both Praed and HD were early architects of both modern lesbian identity and queer writing. Related at least in part to anxiety over their sexuality, they experienced repeated states of dysphoria and even psychosis that, although personally debilitating, were also the source of creativity as both women sought various ways to heal or transcend what HD (1974: 33) describes as a 'break in consciousness' 
that was as much cultural as personal. Their creative strategies, developed independently of any direct influence, have remarkable similarities. From her third novel, Nadine (1882), Praed reveals a marked interest in the incipient field of psychology, which for HD (who was analysed by Sigmund Freud in the 1930s) became centrally important as a personal and creative discipline. At the same time, both writers also relied increasingly on using altered states of consciousness to experience a sense of direct access to a higher reality. In both cases, contact with the numinous was facilitated by a psychic bond with a lesbian lover - Harward in Praed's case; first Frances Gregg and later Bryher in HD's case. For instance, an aural hallucination experienced by Praed and Harward in the south of France in 1911 - recounted by Roderick (1948: 181-7) and reread by Rutherford (2008) as a form of folie à deux - has a close parallel with a visual hallucination (the 'writing on the wall') experienced by HD and Bryher in Corfu in $1920 .^{9}$

Praed's preoccupation with reincarnation also has an uncanny parallel with HD's use of palimpsests, both as a way of understanding the repetition of personal and historical crises and as a structuring device that is one of the hallmarks of her modernist technique. In Nyria (1904), for instance, Praed reconstructs Harward's past life as a slave girl in ancient Rome, as revealed in séances. In HD's Palimpsest (1926: 54, 114), three stories span two millennia: in the first, 'Hipparchia', the eponymous priestess is in a state of 'disembodied ecstasy', which puts her in touch with the 'inner world' of the spirit - a state which her modern incarnations strive less successfully to achieve. Praed's early explorations of disembodiment and different embodiment presage the more extreme manifestations in HD, whose genderless initials and plethora of pseudonyms signal a bodily dysphoria that she attempts to heal or transcend through art. When her photograph was published for the first time in 1923, HD claimed that her life's work had been ruined: the initials 'HD' could have been 'pure spirit', but with the photograph she was 'embodied' (Wolle 1972: 58).

Attuned to living on the margins of sexuality, and with a childhood experience of racial diversity and conflict, both Praed and HD were ahead of their time in their interest in interracial relationships. After visiting Japan and other parts of Asia in 1895, Praed wrote Madam Izàn (1899), a story of interracial marriage. The tall, goddess-like Englishwoman Izobel Carmichael chooses the small dark Japanese lawyer, Izàn Shirazaka, over the big, blustering Australian John Windeatt, who feels entitled to force himself upon her. ${ }^{10}$ Praed here deliberately exaggerates what convention and eugenic theory would see as the couple's physical mismatch to suggest that one's body does not necessarily fit one's soul; and in the end the touching 'true mate' union of the somewhat androgynous Izobel and the somewhat feminised Shirazaka renders Windeatt grotesque and antediluvian. Writing about her adolescent self, the extremely tall HD (1926: 106-7) expresses a similar sense of dysphoria: 'The soul was called Mignon [i.e. small], but, clearly, it did not fit its body'. It is a relatively small step to envisage an interracial relationship, though apparently for HD a step too far to envisage social acceptance of such couples. In 1930, HD collaborated on and (under the pseudonym Helga Doorn) acted the role of Astrid in Kenneth Macpherson's (1930) avant garde silent film Borderline, in which a black couple, Pete and Adah (played by Paul Robeson in his first film role and his wife Eslanda), arrives in a Swiss village. Astrid has an affair with Pete, as does Thorne with Adah. The film ends tragically: Thorne stabs his wife 
to death, Pete is accused of murder but then acquitted, and the black couple is cast out of town. HD wrote that Astrid and Thorne were 'borderline' cases in the psychoanalytic sense, deliberately chosen to offset Pete and Adah, who 'dwell on the cosmic racial borderline' (1930: 6). ${ }^{11}$

Although she was not a direct witness to frontier violence, HD became - like Praed - increasingly obsessed by the racial conflict of the colonial past of her Moravian community of origin in Bethlehem, Pennsylvania, which had been founded as a mission to the Indians. In the aforementioned 'writing on the wall' episode, HD began to sing and dance a series of 'Indian dance-pictures' in which she assumed various personae, including Minnehaha, a medicine man gathering plants, a Spanish woman, a Japanese girl and a Tibetan priest. Just as Praed internalised and projected herself into her father's memories of the Hornet Bank retaliations, HD appropriated her grandmother's memories of a time of frontier violence that was at odds with the official Moravian version of settlement. In London during World War II, with her mental health disintegrating, HD wrote a short story, 'The Death of Martin Presser' (1965), in which she projected herself into the mind of a Moravian missionary at the point of death during a massacre by Indians. Presser's doomed longing to unite Christian and Indian religions in a 'mysterious unity that would be wholly Spirit' (1965: 225) mirrors the complete absence of genuine dialogue with the Other which characterises HD's and Praed's revisionary fantasies of atonement for the sins of the coloniser. Binaries ultimately refuse to be reconciled, continually collapsing into an in-between state of cognitive dissonance such as the one Elsie Valliant experiences in Praed's Outlaw and Lawmaker (published in 1893) while watching a corroboree: 'The shouts grew louder and wilder. The gleaming forms went faster. The red lights became lurid. The acrid barbaric odour intensified. Elsie felt giddy and became faint' (Praed 1988: 224).

\section{Francis Adams}

In Brisbane in 1888, seven years after Praed's Policy and Passion alarmed publisher George Bentley, a tale of the massacre of Aboriginal people on Cape York Peninsula - 'The Red Snake' by Francis Adams - was published in the Christmas edition of William Lane's Boomerang. ${ }^{12}$ Adams was a prolific journalist, poet and novelist whose death just before his thirty-first birthday has consigned him to relative oblivion, a fate not helped by his penchant for publishing - like HD — under pseudonyms and initials that evoke disembodied and differently embodied selves, including Agnes Farrell, Annie Hassal, Frank Hawkesbury, Proteus, F. Adams and F.A. ${ }^{13}$ Born in Malta in 1862, Francis William Lauderdale Adams was the son of the Scottish army surgeon Andrew Leith-Adams and the novelist Bertha Jane LeithAdams. He had a peripatetic childhood, frequently separated from his parents as he criss-crossed the western empire: Malta, New Brunswick in Canada, Ireland and England (where he was educated at Shrewsbury School). In early adulthood, he spent several years in England and France before travelling east to Australia, China, Japan and Egypt. After a period with The Bulletin in Sydney, he lived in Brisbane on and off for four years between early 1886 and late 1889, writing for the local Courier and Boomerang, in addition to The Bulletin. During this time, he also visited regional areas including Toowoomba in search of copy. His first wife Helen and infant son Leith died in Brisbane in 1886, and from 1887 he lived 
there with his second wife Edith. ${ }^{14}$ After returning to England in 1890, Adams committed suicide in Margate, Kent in 1893: suffering from throat cancer as well as tuberculosis, he shot himself during a severe haemorrhage in the presence of Edith, who was reprimanded at the inquest for not intervening to restrain him.

A political radical who believed that violence may be necessary to effect change, Adams joined the Social Democratic Federation in London in 1883. His collection of poems, Songs of the Army of the Night (1888b) was a passionate plea for a workers' revolution. In the preface, Adams requests that the collection 'be looked on as the product of the life of a social worker in England, on his Travels, and in Australia'. His attack on the pernicious effects of capitalism is based on experiences with working people in London, but echoes his own life as an impoverished, consumptive writer:

The vast edifice of our Civilisation is built on the essential wrong of recompensing Labour, not according to the worth of its work, but according to the worth of its members in the market of unlimited competition, and that soon comes to mean the payment of what will hold body and soul together when in the enjoyment of health and strength. (1888b: 11)

The tuberculosis rapidly destroying his young body may explain some of the passionate urgency of the verse, and indeed Adams justifies the inclusion of 'fierce' and 'bloodthirsty' poems by recourse to his own autobiography which, although a free thinker, he sketches in terms of a Christian journey:

I make no apology for several poems in the First Part ['England'] which are fierce, which are even bloodthirsty ... Rather, let me ask you, whoever you be, to imagine what the cause was, from the effect in one who was (unhappily) born and bred into the dominant class, and whose chief care and joy in life was in the pursuit of a culture which draws back instinctively from the violent and the terrible. I will go further. I will arraign my country and my day, because their iniquity would not let me follow out the laws of my nature, which were for luminosity and quiet, for the wide and genial view, but made me 'take arms against a sea of troubles,' hoping only too often 'by opposing to end them.' No, we make no apology for bloody sweat and for tears of fire wrung out of us in the Gethsemane and on the Calvary of our country; we make no apology to those whom we have the right to curse. (1888b: 12)

In the preface, Adams also acknowledges his travels around the empire as central to the formation of his world-view and politics. Like Praed, he sees Ireland as the template of England's colonial 'sin' and its punishment:

the sight of the sin which England has committed not only against herself, against Ireland, against Scotland, but against India, against China, against the sweetest and gentlest people in the earth, the Japanese - the sight of this, and of the signs of England's doom, the punishment for the abuse of the greatest trust any modern nation has had given to her, inspires a hatred which only that punishment can appease. (1888b: 13$)$

By contrast, Adams claims that the 'key-note' of 'Australia', the final part of the Songs, is 'hope' - albeit 'hope that dreads but does not despair'. He dedicates the volume to every 'Man or woman, girl or boy, labourer, mechanic, clerk, houseservant, whoever you may be, whose wages are not the worth of your work ... in 
the hope that you may formally enrol yourself in the Army of the Night' to right the wrongs of capitalism (1888b: 15$).{ }^{15}$

The Preface to Songs of the Army of the Night is signed 'Sydney, Christmas, 1887'. Adams's 'The Red Snake' — published exactly one year later — also deals with violence, but it is a far more enigmatic work, raising ontological problems that are intractable to political analyses and solutions. Using an act of colonial barbarism to explore the intersection of culture and nature in Western civilisation, the story concludes on a disturbingly ambiguous note. What deflected Adams, if only temporarily, from the certainties of revolutionary politics? At least part of the answer appears to lie in his unsettling proximity to the frontier in Queensland.

In 'The Red Snake', a frame narrator (who closely resembles Adams) listens to a story told by Frank Melvil of Maidenhair Passage (recognisable to Queenslanders as the infamous Frank Jardine) in the comfortable Brisbane home of his friend Power (possibly based on Adams's friend, Courier journalist Reginald Spencer Browne) on Christmas Day 1888. Melvil describes how he impersonated the god Biame to subdue the local Indigenous people. Forewarned by an infatuated Indigenous woman that a young warrior known as the Red Snake has organised a raid to kill him, Melvil sets a trap. He shoots the other fourteen warriors, and hangs the Red Snake from a tree to be dismembered and devoured by dingoes. Seduced by Melvil's charismatic voice and presence, but profoundly disoriented by his story, the frame narrator swoons. The story concludes when the narrator awakens to the solicitous attentions of Power and Melvil: the face of Melvil is 'even tender' (McKay 2008b: 124). Technically, the story is innovative in the complexity of its first-person narration, its interest in the fleeting moment and temporal distortion, its anticipation of 'stream of consciousness' and its lack of closure. Moreover, Melvil's tale is repeatedly interrupted by the narrator's interior monologue, which is imbued with homoeroticism. By any measure, this is a confronting and ambiguous story, and even more so as Christmas Day reading matter.

'The Red Snake' also strikingly prefigures the fiction of Joseph Conrad, who did not begin publishing until 1893. Conrad is one of a group of innovative novelists — including Stevenson and Henry James — who straddle the Victorian and Edwardian eras but whose style and preoccupations are increasingly seen as linked to modernism. Like Conrad some years later, Adams uses a frame narrator to create ironic distance and ambiguity in a story of horror at the margins of empire within a story of male comradeship set in relatively civilised Brisbane. The story evokes liminality, a transitional state where identity begins to dissolve, leading to disorientation but also an openness to new things. It is an inconclusive tale about moral darkness, unease and disease in which dialectical tension between opposites (white/black, light/dark, female/male, passivity/dominance, innocence/experience) collapses into ambiguous in-between states. Reminiscent not only of Conrad in 'The Secret Sharer' (1910) and Heart of Darkness (1899), but also Stevenson in The Strange Case of Dr Jekyll and Mr Hyde (1886), Adams explores doubling: there are two narrators, two dead women (one white, one Aboriginal), two dead children (one white, one mixed race), two settings (the 'civilised' world of Brisbane and the northern frontier of Cape York) and two races. There are also two plot-lines: Melvil's account of the massacre, and the narrator's internal journey of self-discovery. Indeed, much of the meaning of the story resides in the psychologisation of the frame narrator as he responds to the horror of the story and attempts 
to understand the inner narrator (Melvil). As in Heart of Darkness, this highly polished story is unified by elaborate motifs and a compelling voice that speaks into the night, but its literariness is in stark contrast to the subject-matter of a journey to a heart of darkness, where civilisation is stripped away. Finally, the amoral figure of Melvil is eerily similar to Kurtz in Heart of Darkness - although, unlike Kurtz, he remains alive and well, able at the end of his chilling account to be 'tender' to the frame narrator.

What are we to make of these uncanny parallels? Since there is no question of mutual influence between Adams and Conrad, we need to look at the broader cultural context that is generating modernity and its literary expression in modernism. Melvil's attack on the hypocrisy of 'civilisation' is one starting point:

What is civilisation but pretence? Every social relation is a fraud. The very basis of it all - clothing - is one gigantic lie. For me, I prefer reality. A man's soul should be in his body, not in his clothes. This sickly, barbarous, 'civilised' hypocrisy disgusts me. Give us healthy, primal relations. They say we have sprung from apes, and certainly I think that we are going back to them. (McKay 2008b: 117)

Adams followed his father in being an admirer of Charles Darwin, and there was a personal connection: in 1878, Andrew Leith-Adams was appointed to the Chair of Natural History at Queen's University in Cork on Darwin's recommendation. However, Darwinian theory was of interest to the mature Adams principally for its cultural implications. His concept of being a 'modern' was to be 'thoroughly Cultured, thoroughly Scientific, thoroughly Socialistic' (letter to William Michael Rossetti, 7 November 1889, cited in Tasker 2001: 224). In the passage quoted above, Melvil implies that in stripping human life of any divine purpose, evolutionary theory has undermined the basis of conventional social relations and moralities, leaving embodiment as our only reality. From there, it is a short step to Melvil's overweening sense of his own fitness to rule over the local people, whom he is able to subdue through his post-Darwinian awareness that belief in a transcendent purpose is a weakness to be exploited:

I would say to the young men: 'I am Biame, the figure of the man!' Then to the others I would add, raising my voice and speaking to each according to his grade: 'Know me in the whirl of the boomerang! Know me in the rush and stab of the spear! Know me in the irresistible flash of the lightning! I am Biame. I slay you!' With that I would shoot the man right through the heart. It was because I knew their language and religion and social laws so well that I could bring new ideas of force and terror into them. (McKay 2008b: 119-20)

Perhaps Adams - somewhat in the manner of his political dialogues - is giving voice through the character Melvil to a particularly grotesque form of social Darwinism, a movement that he personally rejected (see Adams 1890).

Evolutionary theory also leads to a form of cognitive dissonance in cultural production. 'The Red Snake' exemplifies a narrative device that Richard Lehan (2005: 190-1) observes in naturalist fiction of the period, namely the displacement of 'an overcivilised person from the urban realm into a more primitive setting':

The theory of evolution presumes that we are conflicted - a rational self competes with an irrational self, a remnant of human evolution. This second self embodies 
a Dionysian element ... First, it can appear as the romantic self, searching for some kind of essential meaning. Second, it can manifest itself in the form of the artist, sensitive to both the beauty and the chaos that underlies material reality. Thirdly, it can express itself in the form of compulsions, desires and events that cannot be turned off. And lastly, it can emerge as a destructive element, a kind of chthonian impulse, capable of moving an individual to commit some extreme crime or of initiating physical or moral decline in him or her.

In Adams's story, the frame narrator struggles to create meaning out of the fragments of beauty and chaos that penetrate his passive body through his eyes and ears. Melvil, on the other hand (like Conrad's Kurtz), represents the chthonian impulse, and refuses the search for meaning as if that quest were just another manifestation of 'pretence' and 'sickly ... hypocrisy': although an educated man, he informs his listeners that 'I think very little' (McKay 2008b: 117). While it is unlikely that Adams would have encountered the work of Friedrich Nietzsche, he had certainly read Walter Pater, whose work on the dialectical tension between the Apollonian and Dionysian anticipated Nietzsche and, as I have suggested elsewhere (McKay 2008a), appears to have directly influenced 'The Red Snake'. Both Nietzsche and Pater drew heavily on Karl Müller's Die Dorier (1824), published in English as The History and Antiquities of the Doric Race in $1830 .^{16}$

'The Red Snake' is a form of thought experiment that closely resembles Adams's fictional 'dialogues' on social issues published in his critical commentaries. In Adams's political writings, violence produces movement or breakthrough, but his attitude to violence on the frontier is ambiguous here. It is worth comparing this story with his earlier experiment with the representation in fiction of colonial violence as cognitive dissonance. In May 1888, the story 'Tony Forster' by Proteus — one of Adams's pseudonyms — appeared in the Boomerang (Adams 1888c). ${ }^{17}$ Tony is a gentle giant who 'wouldn't hurt a fly', but when his friend Jimmy Jackson is speared, Tony drives thirteen Aboriginal people into a cave and kills them one by one:

None of 'em made a sound, except a low sorter whispering like blind pups. I caught hold of one by the neck with my hand and lugged him out and smashed his skull in with a blow of the tomahawk. Then I reached in and got hold of another. It was a gin, and I got her out by the leg and pulled her out, and 'bout broke her head off with a crack on the back of the neck. Then I got another one and smashed his skull in like the first one. And all the while I was reaching in and pullin' 'em out they never made a sound, but kept up that sorter wimperin' like pups when the mother's gone. I killed the whole lot. There was thirteen of 'um. I counted. (1888c: 11)

As in the later story, Tony Forster recounts his tale in explicit and shocking detail to the frame narrator as they sit in a dark room, but unlike the calm and mellifluous Melvil, Tony is 'transfigured' during the tale into 'something like a gigantic python' (1888c: 11 ).

'Tony Forster' is a less polished and less complex version of Adams's thought experiment in 'The Red Snake'. Unlike Melvil, Forster is an uneducated and simpleminded man who reacts in the heat of the moment to what he sees as the unprovoked murder of a friend, and is incapable of providing this episode of frontier violence with any ethical or philosophical context. 'The Red Snake' is more profoundly 
shocking because of the deliberate, premeditated actions of Melvil, and his seductively articulate justification of them on the basis of his superior might. Nonetheless, the conclusions of the two stories are remarkably similar in that the narrators, while making no direct comment on the tales they have heard, re-establish the humanity of the violent actors in a way that compounds rather than alleviates the cognitive dissonance. Forster, remembering his mate Jimmy, 'bent his head down into his arms on the table, and his great body shook to his sobs'; Melvil is 'tender' (McKay 2008b: 124). Neither narrator offers any direct comment on the tales they have heard, but Adams later argues in his non-fiction work The Australians (1893: 154) that although there are 'cruel' and 'horrible' features in colonial life, 'even in these there is an intensity, a directness, and a reality, which lift them ... right above the eternally hideous and hypocritic vice of all the phases of our so-called "Civilisation"'. However, to read 'The Red Snake' as valorising Melvil's actions would be to ignore the story's carefully constructed dialectic tension between light and dark, femininity and masculinity, passivity and dominance, innocence and experience. Unresolvable, these opposites are finally sucked into a vortex, leading to the collapse of the 'overworked, sick, feverous' narrator in a passage curiously reminiscent of Praed's description of Elsie Valliant fainting while watching a corroboree:

Then all grew confused, whirling, thudding terribly like a train at full speed, convoluting and extending itself in mid-air like a long thin snake, and whirled away into the rushing darkness and silence. (McKay 2008b: 124)

Like the indisputably modernist Vorticists twenty-five years later, Adams is creating and collapsing cultural dichotomies in order to 'blast' culture out of its Victorian stasis - and indeed this collapse seems to mirror the destabilisation of the centreperiphery model of cultural influence itself.

\section{Frank Jardine}

Although the paths of Rosa Praed and Francis Adams never crossed in the flesh, their imaginative worlds intersect tellingly in their fictional portraits of the infamous Francis Lascelles 'Frank' Jardine (1841-1919), whose ruthlessness was a lightning rod for colonial guilt. In Praed's Lady Bridget in the Never-Never Land (1987) Colin McKeith scores the barrel of his gun with a notch for every 'black-fellow' that he kills, just as Jardine ruled Somerset with a Terry rifle with 47 notches on the stock for confirmed killings of Aboriginal people (Bayton 1965: 631). Despite her long absence from Queensland, Praed was well informed about Frank Jardine because her sister Lizzie was married to his younger brother. Adams's Melvil of 'Maidenhair Passage', 'the point where the Great Barrier Reef comes in closest to the coast' (McKay 2008b: 112), likewise would have been instantly recognisable to Queenslanders as Frank Jardine of Somerset, which overlooked Albany Passage at the tip of Cape York. These depictions of a highly controversial figure signal not only a shared preoccupation with racial violence as a source of cognitive dissonance in colonial society, but also a shared desire to transplant him - and the settler dispossessory colonial experience more generally - from the periphery into the consciousness of readers around the Anglophone world. Just as Marlow in Conrad's Heart of Darkness insists that Kurtz is the acme of European civilisation, both Praed and Adams portray their Jardine characters as superior examples of British 
manhood, whose ruthless racial violence cannot be dismissed as an aberration, but must be seen as inherent in and essential to the imperial project.

\section{Conclusion}

Friedman's (2010) proposition that literary modernisms are multiple, polycentric and recurrent suggests that a re-evaluation of Queensland literature and its relation to the metropolitan centre is overdue. This article has taken up her invitation to explore the circulation of people and ideas that connect modernisms from different parts of the planet by reconsidering two moments in the literature of colonial Queensland as instances of proleptic modernism. The publication of Policy and Passion by Rosa Praed in 1881 in London, and that of 'The Red Snake' by Francis Adams in 1888 in Brisbane both encapsulate early manifestations of the cultural unease and destabilisation that drive the development of modernism/s as the expressive domain of modernity/ies. Striking thematic and stylistic parallels between the work of writers unconnected by any direct influence - Praed and HD, and Adams and Conrad respectively - suggest not only that modernism begins to manifest itself in Anglophone culture much earlier than is generally conceded, but also that the colonial experience is centrally implicated in its development. The racial and sexual violence of contact zones generate a cognitive dissonance that destabilises the self, but paradoxically provides an 'entry into the extraordinary' for writers like Praed and Adams, driving their creative pursuit of modernity in the form of new thematic preoccupations and textual strategies that uncannily anticipate the work of canonical literary modernists like HD and Conrad whose work similarly lives on the cultural faultlines. The transnational cultural formations of Praed, a child of the contact zone in remote Queensland who moved to the metropolitan centre and made the colonial experience an essential component of cosmopolitanism, and Adams, a peripatetic cosmopolitan from childhood, suggest that colonial Queensland is worth exploring further as one of the multiple and polycentric incubators of literary modernism.

\section{Endnotes}

1 On the cultures of movement that brought colonial subjects to Britain, and the intercolonial and transnational exchanges taking place there, see Booth and Rigby (2000), Burton (1998) and Snaith (2014).

2 Reverse migration to Europe was not unusual, and migration between various British colonies - especially but not only the other Australian colonies and New Zealand — was commonplace.

3 Clarke (1999: 13-14) speculates that Thomas Lodge Murray-Prior may have been Jenny's father. After bathing the child, he had her dressed in Rosa's clothes, and at Hawkwood station she slept in the bedroom of Murray-Prior and his wife. Murray-Prior, who had twelve children by his first wife Matilda Harpur and eight by his second wife Nora Barton, was reputed also to have had many illegitimate children.

4 Reid, based in part on Thomas Lodge Murray-Prior's 'reliable' account later dictated to his daughter Rosa, concludes that whites believed that there was a 'conspiracy to wipe them out': 'They believed treachery stalked the night, and occasionally they saw it peeping in their windows' (Reid 1982: 84). Murray-Prior's station Hawkwood, also known as Naraigin, was just to the east of Hornet Bank. Reid observes that 'for some years in the mid-1850s, the 
frontier virtually stood still on a line running from Hornet Bank station in the west ... to Palm Tree Creek and Gwambagwyne stations down the Dawson' (1982: 7-8).

5 See also Clarke (1999: 16-19).

6 For this account of the correspondence, I am indebted to Clarke (1999: 58-62). She notes that under pressure from Bentley, Praed 'eliminat[ed] most of the scene in which Barrington attempted to seduce Honoria' (1999: 60).

7 Barlow (1996) argues that Praed and Harward had a 'Boston marriage', and that they understood their relationship through the discourse of theosophy. For a discussion of Rosa Praed's spiritualism, see Ferres (2004).

8 When Colin McKeith describes his killing of King Mograbar, his Irish wife Lady Bridget retorts, 'How cruelly unjust. It was his country you were stealing ... I don't admire your glorious British record, I think that it's nothing but a record of robbery, murder and cruelty, beginning with Ireland and ending with South Africa' (Praed 1987: 47). Carr (2000: 75) reads the Celtic Revival as not only a Romantic idealisation of the past or a vehicle to support political independence, but also as a bridge to Anglo-American modernism: 'It gave to the modernists a model for change that looked not simply to the past but to an alternative cultural tradition from which and by which to critique the values of present power structures and Western modernity.'

9 The first part of HD's Tribute to Freud is entitled 'The Writing on the Wall' in acknowledgement of the central role this episode had in HD's analysis by Freud.

10 Platt (2008: 41) criticises Praed's treatment of her childhood romance with an Aboriginal man, Ringo, as 'knowingly mocking rather than seriously romantic', but the arch and ironic tone resembles that of later modernists like Virginia Woolf in Orlando or Djuna Barnes in The Book of Repulsive Women when concealing the seriousness of explosive subject-matter with apparent flippancy.

11 HD probably wrote the script, and certainly participated in the montage: see McKay (1985: 149-50; 197 n. 16).

12 See Adams (1888a). A revised version was published in Australian Life (see Adams 1892a). Quotations here are from my critical edition (McKay 2008b); for a detailed analysis of the story see McKay (2008a).

13 For a listing of works by Adams, and his pen names, see Tasker (1996).

14 Although they presented themselves as a married couple, there is no record that Edith Goldstone and Francis Adams were legally married: see Tasker (2001: 205).

15 In 1894, Adams's friend Henry S. Salt published a revised edition of Songs of the Army of the Night (Adams 1894), which included — in accordance with revisions by Adams himself the 'Mass of Christ'. This poem, first published in The Bulletin in 1893, sheds further light on Adams's attraction to the figure of Jesus but shows contempt for organised Christianity, which the poem rejects in favour of a new vision of hope that appears in female guise as both 'wife' and 'soldier'. See Tasker (2001: 123-8).

16 For a discussion of the British precursors of Nietzsche, see Bridgwater (1978: 230-4).

17 The story is set in Toowoomba, where Adams lived briefly, and Proteus is the narrator of the story as well as its author. 'Tony Forster' was later republished by Francis Adams (1892b) as 'Long Forster' in Australian Life, where the revisions made by Adams further emphasise Forster's simple-mindedness and lack of education.

\section{References}

Adams Francis 1888a. 'The red snake', The Christmas Boomerang, 24 December, pp. 17-18. 
- 1888b. Songs of the army of the night. Sydney: Federal Steam \& Binding Works.

— [as 'Proteus'] 1888c. 'Tony Forster', The Boomerang, 5 May, p. 11.

— 1890. 'A Note on Mr Herbert Spencer', Centennial (Sept.), pp. 108-14.

— 1892a. 'The Red Snake', in Australian life. London: Chapman \& Hall, pp. 3-24.

— 1892b. 'Long Forster', in Australian life. London: Chapman \& Hall, pp. 137-47.

— 1893. The Australians: A social sketch. London: T. Fisher Unwin.

— 1894. Songs of the army of the night, rev. ed. Henry S. Salt. London: William Reeves.

Barlow Damien 1996. “"My little ghost-slave”: The queer lives of Rosa Praed', Australian Literary Studies 17(4): 344-52.

Bayton John 1965. 'The mission to the Aborigines at Somerset', Journal of the Royal Historical Society of Queensland 7(3): 622-33.

Bridgwater Patrick 1978. 'English writers and Nietzsche', in Malcolm Pasley (ed.), Nietzsche: Imagery and thought - a collection of essays. London: Methuen, pp. 220-56.

Burton Antoinette 1998. At the heart of the Empire: Indians and the colonial encounter in late-Victorian Britain. Berkeley, CA: University of California Press.

Booth Howard J. and Rigby Nigel (eds) 2000. Modernism and empire: Writing and British coloniality, 1890-1940. Manchester: Manchester University Press.

Carr Helen 2000. 'Imagism and empire', in Howard J. Booth and Nigel Rigby (eds), Modernism and empire: Writing and British coloniality, 1890-1940. Manchester: Manchester University Press, pp. 64-91.

Clarke Patricia 1999. Rosa! Rosa! A life of Rosa Praed, novelist and spiritualist. Melbourne: Melbourne University Press.

Ferres Kay 2004. 'Rosa Praed and spiritualism', ACH 23: 7-23.

Friedman Susan Stanford 1981. Psyche reborn: The emergence of HD. Bloomington, IN: Indiana University Press.

— 1990. Penelope's web: Gender, modernity, HD's fiction. Cambridge: Cambridge University Press.

2010. 'Planetarity: Musing modernist studies', Modernism/Modernity, 17(3): 47199.

HD 1926. Palimpsest. Boston: Houghton Mifflin.

- 1930. Borderline, pamphlet, n.p.

— 1965. 'The death of Martin Presser', Quarterly Review of Literature.

— 1974. Tribute to Freud. Boston: David R. Godine.

LaCapra Dominick 2001. Writing history, writing trauma. Baltimore, MD: Johns Hopkins University Press.

Lamond Julianne 2012. 'The Anglo-Australian: Between colony and metropolis in Rosa Praed's "The Right Honourable" and "Policy and passion"', Australian Literary Studies 27(1): 33-46.

Lehan Richard 2005. Realism and naturalism: The novel in an age of transition. Madison, WI: University of Wisconsin Press. 
McKay Belinda 1985. 'HD: Her life and work', unpublished $\mathrm{PhD}$ thesis, University of Oxford, https://ora.ox.ac.uk:443/objects/uuid:fee18106-59c6-42ea$8 \mathrm{c} 80-2 \mathrm{c} 3$ efe $6 \mathrm{~b} 72 \mathrm{~b} 3$.

_ 2001, “"The one jarring note”: Race and gender in Queensland women's writing to 1939', Queensland Review 8(1): 31-54.

_ 2008a. 'Narrating colonial Queensland: Francis Adams, Frank Jardine and "The Red Snake"', Queensland Review 15(1): 97-109.

— (ed.) 2008b. “"The Red Snake” by Francis Adams', Queensland Review 15(1): 111-29.

Macpherson Kenneth (dir.) 1930. Borderline. Pool Films.

Müller C.O. 1830 [1824]. The history and antiquities of the Doric race. Trans. Henry Tufness and George Cornewall Lewis of Karl Otfried Müller's Die Dorier. 2 vols. London: John Murray.

Platt Len 2008. "“Altogether better bred-looking”: Race and romance in the Australian novels of Rosa Praed', JASAL 8: 31-44.

Praed Rosa 1881. Policy and passion: A novel of Australian life. London: Richard Bentley.

— 1882. Nadine: The study of a woman. London: Chapman \& Hall.

- 1885. Australian life black and white: Sketches of Australian life. London: Chapman \& Hall.

— 1899. Madam Izàn: A tourist story. London: Chatto and Windus.

- 1902. Fugitive Anne: A romance of the unexplored bush. London: John Long.

- 1904. Nyria. London: G. Bell.

— 1916. Sister Sorrow: A story of Australian life. London: Hutchinson.

1987 (1915). Lady Bridget in the Never-Never Land. London: Pandora.

1988 [1893]. Outlaw and lawmaker. Sydney: Pandora.

Reid Gordon 1982. A nest of hornets: The massacre of the Fraser family at Hornet Bank Station, Central Queensland, 1857, and related events. Melbourne: Oxford University Press.

Roderick Colin 1948. In mortal bondage: The strange life of Rosa Praed. Sydney: Angus \& Robertson.

Rutherford Jennifer 2008. 'Melancholy secrets: Rosa Praed's encrypted father', Double Dialogues 8, http://www.doubledialogues.com/article/melancholy-secretsrosa-praeds-encrypted-father.

Snaith Anna 2014. Modernist voyages: Colonial women writers in London, 1890-1945. New York: Cambridge University Press.

Stevenson Robert Louis 1996 [1886]. The strange case of Dr Jekyll and Mr Hyde. New York: HarperCollins.

Sword Helen 2002. Ghostwriting modernism. Ithaca, NY: Cornell University Press.

Tasker Meg 1996. Francis Adams: A research guide. Brisbane: University of Queensland Press.

2001. Struggle and storm: The life and death of Francis Adams. Melbourne: Melbourne University Press. 
Belinda McKay

Wolle Francis 1972. A Moravian heritage. Boulder, CO: Empire Reproduction and Printing.

Woolf Virginia 1924. Mr Bennett and Mrs Brown. London: Hogarth Press. 